\title{
Students' Critical Thinking Performance through Problem-Based Learning by Using Metacognitive Strategy
}

\author{
N Hidayah' ${ }^{1}$, N M D Putra ${ }^{2}$, Sugianto ${ }^{3}$ \\ ${ }^{1,2,3}$ Graduate School, Universitas Negeri Semarang, Indonesia \\ ${ }^{1}$ Corresponding email: noorhidayah1993@yahoo.co.id
}

\begin{abstract}
The purpose of this research is to examine the performance of Problem Based Learning (PBL) by metacognitive strategy and critical thinking profile achieved by the students. The research used mix method with type explanotary sequential, while the research planning with the type of pre-test post-test control group design. The Subjects were the XI grade students in SMA 1 Kudus in the academic year 2017/2018. Data collection used essay questions and interview to describe the students' critical thinking ability on optical devices. The research result showed that PBL by using metacognitive strategy was effective to improve the students' critical thinking than PBL. The metacognitive strategy used in PBL learning trains the students to think to solve the problems faced. PBL by using metacognitive stategy has performed the higher score in indicator of asking and answering the questions, making and considering result, and integrating, but performance score was lower than the indicator which formulates questions, doing observation and assessing observation result report and defining and assessing the definition.
\end{abstract}

Keywords: Critical, Metacognitive, PBL

\section{Introduction}

The 21 century development needs a skill to prepare the students in the future. The skill which must by owned in the 21 century are critical thingking, problem solving, information literacy, and global awareness (Rotherham and Willingham, 2009). The 21 century skill can be applied in the education field. Critical thinking is one of the forms of high order thinking. It involves the high level in physics competency that must be owned by students.

This research related to critical thinking is not a new one. Some previous researches show that the students' critical thinking has not developed well. The university students' critical thinking skill in the medium and low level in the indicator of identifying and correcting concept and analyzing (Zetriuslita, 2016). Critical thinking skill in the fluida statistic in Senior High School students is still in low category in the indicator of basic clarification, the basic in taking the decision, inference, advanced clarification, and strategy and tactics (Puspita, Kaniawati, and Suwarma, 2017). Online learning shows that the university students' critical thinking skill is still in the low level in the indicator of understanding and analyzing (Rusdi and Umar, 2015).

The undeveloped critical thinking skill is caused by several factors. A student's necessity in active learning by relating the problem in the daily life (Yuliati, Fauziah, and Hidayat, 2018). One of the active learnings problem based is PBL. PBL can improve the critical thinking skill by using daily case and problem to get knowledge and create innovation in solving the problems (Birgili, 2015). PBL consists of process stages which can improve the students' critical thinking skill, students' self ability, and work together in the heterogeneous group (Ullynuha, Prayitno, and Ariyanto, 2015). The hetereneous group discussion process facilitates the students to inquire.

The learning in the village and the the city need to develop metacognitive orientation to improve physics skill (Pimvichai, Yuenyong, and Thomas, 2015). Metacognitive strategies in learning are helping students to plan, monitoring and controlling from what to know, what to to do and how to do (Maulana, 2008; Namira, Kusumo, and Prasetya, 2014). Metaconitive strategy can improve critical thinking skill. The is high correlation between critical thinking skill and metacognitive strategy, because students determine their own purpose to reach, monitoring and using the strategy to improve the learning quality (Gurcay and Ferah, 2018). That's why, we need to do performance critical thinking research through PBL by using metacognitive strategy and critical thinking profile achieved by the students. 


\section{Methods}

The method in this research was mix method. Mix method is collaborating qualitative and quantitative method. The research design used explanatoris sequential type whiche means the first phase of the research used quantitative method dan in the second phase used qualitative research. The data collection design used pre-test post-test control group design type. The subjects used in this research were the students of XI grade MIPA 9 as the experiment class and XI grade MIPA 8 as the control classin SMA 1 Kudus academic year 2017/2018. The research procedure was pre field phase, field phase, and post field phase. The data collection technique used essay questions about students critical thinking skilland interview. Qualitative data analysis used normality test, homogeneous test, average test, classical completeness test and improvement test, while qualitative used descriptive analysis based on students critical thinking indicator from students' written answer and interview data. Then quantitative and qualitative data were combined to answer the problem formulation.

\section{Results and Discussion}

This research used two class samples as control class and experiment class. The data collection was begun by giving pretest to know the beginning condition from the two classes. Then it was done pretest. They were the normality test shows the statistic used was parametric statistic, homogeneous test shows the two classes has the same variety, and the two classes average test shows the two classes were not significantly different.

The two sample classes was given the different treatments. They were experiment class used PBL by using metacognitive strategy and the control class used PBL. The learning material given was about optical devices include eyes, camera, magnifying glass, microscope and telescope. The materials were provided in the learning materal validated by the experts. In the last meeting the two classes were given to know the achievement and the improvement toward the critical thinking after the treatment from each class. The Instrument used to measure the critical thinking was essay questions. The indicator of critical thinking used from Ennis was formulating questions, questioning and answering the questions, doing and assessing observation result report, making and considering result, defining and assessing definition and also combining (Ennis, 2011).

\subsection{The effectiveness of PBL by using the metacognitive strategy toward the critical thinking}

The effectiveness of PBL by using the metacognitive strategy toward critical thingking done several tests some of them are clasical completeness test and improvement test. The clasical completeness test result is in experiment class shows $Z_{\text {count }}>Z_{\text {table }}$ so $H 0$ is rejected, which means students' proportion with critical thinking score $\geq 70$ has passed $75 \%$. Students' critical thinking has passed the completeness proportion classically $90.32 \%$ in the experiment class. The classical completeness test result in the control class shows $Z_{\text {count }}>Z_{\text {table }}$ so $H 0$ is accepted, which means the students' proportion with the critical thingking score $\geq 70$ has not passed $75 \%$. The students' critical thinking has passed the completeness proportion classically $67.74 \%$ in control class. Beside that, it is done improvement test uses gain test normalized. Gain test result normalized can be shown on the Table 1 .

Table 1. Critical Thinking Gain Test Normalized Result

\begin{tabular}{|c|c|c|c|c|}
\hline \multirow{2}{*}{ Data } & \multicolumn{2}{|c|}{ Average score } & \multirow{2}{*}{$\begin{array}{c}N- \\
\text { Gain }\end{array}$} & \multirow{2}{*}{ Criteria } \\
\hline & Pretest & Postest & & \\
\hline $\begin{array}{l}\text { Control } \\
\text { Class }\end{array}$ & 21.24 & 74.73 & 0.68 & Medium \\
\hline $\begin{array}{l}\text { Experiment } \\
\text { Class }\end{array}$ & 17.80 & 82.31 & 0.78 & High \\
\hline
\end{tabular}

In the Table 1. shows that the students' critical thinking score increases with the criteria of medium in the control class and high in the experiment class. Based on the classical completeness test and improvement test shows PBL with metacognitive strategy is effective to be applied in learning material of optical devices than PBL.

PBL with metacognitive strategy in physic learning is learning model problem based with teacher and students plan effective learning in achieving the learning goal by using metacognitive strategy. PBL with metacognitive strategy gives impact to the students when they get physic knowledge during learning process. PBL by using 
metacognitive strategy can improve students' metacognitive knowledge by doing syntax learning available (Rahayu and Azizah, 2012).

The usage of PBL learning syntax by using metacognitive strategy helps the students in receiving information or knowledge. Metacognitive used includes planning, information management, observing debugging, and evaluation to get correct argument (Magno, 2010). Planning strategy helps to understand the learning goal and prepare the students to study. Information management strategy includes collecting information obtained by the students by using many sources and students can choose the correct information. Comprehension monitoring strategy helps students to review the provided answers. Debugging strategy is by improving understanding from problem answer if there is mistake. Evaluation strategy gives chances to the students themselves to evaluate the performance and learned material is mastered or not. Metacognitive strategy is also clarified in the material to learn as reminder for students and teacher in order to make the activity run well.

PBL by using metacognitive strategy improves physic critical thinking because by training the students think to solve the problem they faced. Learning using PBL gives impact toward the students' metacognitive skill which impacts in the problem soving faced (Haryani et al., 2018). Beside that, learning by using problem solving based physic needs to use critical thinking skill. PBL give contribution in critical thinking skill about physic material (Bashith and Amin, 2017; Reza, Ibrahim, and Rahayu, 2018; Vitaloka and Sani, 2016).

\section{2. $P B L$ performance using metacognitive strategy toward critical thinking \\ Critical thinking skill is data about} students' ability in solving the problem included six critical thinking indicators. Here is the score of critical thinking skill from postest in the control class and experiment class on Table 2.

Critical thinking score in every indicator has different score. On the table 3.2. above shows that learning in control class and experiment class. The factors influence achieved score in every indicator are not same.

The indicator of formulating questions asks the students to write information in the questions with the questions which must be finished. Based on table 3.2 shows PBL class is higher from PBL by using metacognitive strategy. The second class gets almost perfect score. Overall, it shows that alomost all students can write information from the questions correctly and pricesly.

Table 2. Critical Thinking Ability Performance Score

\begin{tabular}{lcc}
\hline \multirow{2}{*}{ Indicator } & \multicolumn{2}{c}{ Percentage (\%) } \\
\cline { 2 - 3 } & $\begin{array}{c}\text { Control } \\
\text { Class }\end{array}$ & $\begin{array}{c}\text { Experiment } \\
\text { Class }\end{array}$ \\
\hline Formulating questions & 99.19 & 97.58 \\
\hline $\begin{array}{l}\text { Asking and answering } \\
\text { questions }\end{array}$ & 88.71 & 91.40 \\
\hline $\begin{array}{l}\text { Doing and evaluating } \\
\text { observation result } \\
\text { report }\end{array}$ & 81.45 & 75.27 \\
\hline $\begin{array}{l}\text { Making and } \\
\text { considering result }\end{array}$ & 45.56 & 77.22 \\
\hline $\begin{array}{l}\text { Defining and } \\
\text { evaluating definition }\end{array}$ & 97.58 & 95.16 \\
\hline Combining & 34.68 & 40.32 \\
\hline
\end{tabular}

The indicator of asking and answering questions asks the students to know the questions in the questions sheet and answer by using simple step. Based on table 3.2 shows that PBL class by using metacognitive strategy is higher than PBL class. The students know the questions they have to do. But the students are sometimes inverted in writing the formula when they finish the questions.

The indicator of doing and evaluating observation result report asks the students to decide the formula which is precise by evaluating the available information. Based on table 3.2 shows that PBL is higher than PBL class using metacognitive strategy. Overall, the sudents decide the formula correctly in finishing the questions. But some students are wrong in entering the information when they finish the questions. For example: the questions do not give information about the near point eyes when usinng telescope, the students should use near point $25 \mathrm{~cm}$. But some students are wrong in deciding the near point unit and some other students are wrong in deciding scale of near point. That is $20 \mathrm{~cm}$.

The indicator of making and considering result asks the students to make a solving problem process by considering information obtained before. Based on table 3.2 shows that PBL class by using metacognitive strategy can make shadow formation process on the 
magnifier glass precisely and correctly, while in PBL class, only several students can make shadow formation process on the magnifier glass.

The indicator of defining and evaluating definition aks the students to define the parts from on of optical devices. Based on table 3.2 shows that PBL class is higher than PBL class using metacognitive strategy. Both classes get almost perfect score. Overall, it shows that almost all students can define the parts from eyes and camera which has the same function. The students' mistake in answering is caused by being inverted in writing the parts in eyes and camera.

The indicator of asking the students to combine information obtained in solving the problem. The two classes get almost perfect score. Overall, it shows that almost all students can write information from the questions correctly and precisely. In this indicator, the two classes get the lowest score. This is caused the indicator of combining can be finished when the obtained information in the previous step gets the correct answer. The factor influnces the mistake in in the two classes because the students are wrong in deciding the formula and wrong in determining the unit.

The students' critical thingking ability need to be developed as an effort to face the challeinges and problem faced. Critical thinking can be trained by PBL learning. PBL influences in every indicator. The using of PBL can contribute better than conventional learning in improving students' critical thinking in the indicator of formulating questions, asking and answering questions, doing and evaluating definition, making and considering result, defining and evaluating definition, and also combining (Vitaloka and Sani, 2016). Metacognitive strategy used only infuences in some critical thinking indicators. The using of PBL by using metacognitive strategy gives higher score in the indicator of asking and answering questions, making and considering result, and combining, while PBL gives higher score in the indicator of formulating questions, doing observation and evaluating observation result, and also defining and evaluating definition.

\subsection{Citical thinking profle from PBL by using metacognitive strategy}

The triangulation data is done to clarify the written answer by the students and search information related to factor influences the students from the use of PBL by using metacognitive strategy. The triangulation data can be obtained by using test, questionnaire, and interview on six students. Everi representation from the critical thinking group high, medium, and low consists of two students using PBL using metacognitive stategy. Performance score from every representation can be seen on Table 3 .

Table 3. Critical Thinking Skill Profile Score

\begin{tabular}{lccc}
\hline \multirow{2}{*}{ Indicator } & \multicolumn{3}{c}{ Persentage (\%) Group } \\
\cline { 2 - 4 } & High & Medium & Low \\
\hline $\begin{array}{l}\text { Formulating } \\
\text { questions }\end{array}$ & 100 & 99 & 83.33 \\
$\begin{array}{l}\text { Asking and } \\
\text { answering }\end{array}$ & 100 & 92 & 77.78 \\
$\begin{array}{l}\text { questions } \\
\begin{array}{l}\text { Doing and } \\
\text { evaluating } \\
\text { observation result }\end{array}\end{array}$ & 100 & 80 & 11.11 \\
$\begin{array}{l}\text { report } \\
\text { Making and }\end{array}$ & 100 & 79.75 & 33.33 \\
$\begin{array}{l}\text { considering result } \\
\begin{array}{l}\text { Defining and } \\
\text { evaluating } \\
\text { definition }\end{array}\end{array}$ & 100 & 94 & 100 \\
\begin{tabular}{l} 
Combining \\
\hline
\end{tabular} & 100 & 36 & 16.67 \\
\hline
\end{tabular}

The high critical thinking group in PBL by suing metacognitive strategy shows the maxumum score in all indicators. They are formulating questions, asking and answering questions, doing observation and evaluating the observation result report, making and considering result, defining and evaluating definition, and also combining. In the high critical thinking group can answer critical thinking questions precisely and well. The high critical thinking group feels happy to use PBL using metacognitive strategy so they are motivated to understand the material about optical devices metacognitive strategy gives positive influence in critical thinking (Daud and Hafsari, 2015; Magno, 2010). The impact is due to awareness metacognitive owned by the students shows that the students must have the awareness toward the strengths and weaknesses when they are in the learning process. Metacognitive strategy is used to control the thinking in finding information (Magno, 2010). The process of controlling 
high critical thinking group by taking notes on important points in the learning material or note books when the learning activity is ongoing. The important points are the concepts used as the basic or guidance in solving the problem during the learning process.

The medium critical thinking group in PBL using metacognitive strategy shows the maximum score is only in the indicator of formulating questions. The factors influence not to get the maximum score in the other indicators because the students are not complete enough in deciding the objective focus from telescope, preciseless in looking at the unit so they are wrong in deciding the final result, not answering in deciding the enlargement telescope with accommodated eye, feeling confused in deciding the thing distance on the ocular lense, and being inverted in answering the similarity on eyes and camera.

The low critical thinking group in PBL by using metacognitive does not show the maximum score in all indicators. The factors which do not influence not to get the maximum score in all indicators because they cannot take the information from the questions, because they are preciseless in looking at the unit, so they are wrong in deciding the final result, not answering the questions and not understanding the given questions, not answering the questions in deciding the telescope enlagement with accommodated eyes and not accommodated eyes. In the indicator of making and considering result, they are wrong in answering the similarity on eyes and camera, and they are wrong in deciding formula.

\section{Conclusion}

PBL by using metacognitive strategy is effective to improve the students' critical thinking skill than PBL. PBL by using metacognitive strategy has the higher performance score in the indicator of asking and answering the questions, making and considering the result, and combining, but score performance is lower in the indicator of formulatng questions, observing and assessing observation result report and defining and assessing definition.

\section{References}

Bashith, A. \& Amin, S. (2017). Al-Ta'lim Journal 24(2).

Birgili, B. (2015). Journal of Gifted Education and Creativity 2(2).

Daud, F., \& Hafsari, I. A. (2015). Modern Applied Science. 9(12).

Ennis. (2011). Inquiry: Critical Thinking Across Disciplines. 26(1).

Gurcay, D., Ferah, H. O. (2018) Journal of Education and Training Studies. 6(4).

Haryani, S., Masfufah, Wijayati, S., \& Kurniawan, C. (2018). Journal of Physics 983012174.

Magno, C. (2010). Metacognition Learning. 5 (2).

Maulana. 2008. Jurnal Pendidikan Serambi Ilmu. 2(10).

Namira, Z.B, Kusumo, E. and \& Prasetya, A.T. (2014). Jurnal Inovasi Pendidikan Kimia 8(1).

Pimvichai, J., Yuenyong, C., \& Thomas, G.P. (2015) Mediterranean Journal of Social Sciences. 6(3).

Puspita I, Kaniawati, I., \& Suwarma IR. (2017). Journal of Physics. 895012100.

Rahayu, P. \& Azizah, U. (2012) Unesa Journal of Chemical Education. 1(1).

Reza, M, Ibrahim, M, \& Rahayu, Y. S. (2018) Journal of Physics 947012062.

Rotherham, A., J. \& Willingham, D., T. (2009) Educational Leadership. 67(1).

Rusdi, S.H. \& Umar, I.N. (2015). Procedia Social and Behavioral Sciences 197.

Ullynuha, L., Prayitno, B.A. \& Ariyanto, J. 2015. Jurnal Pendidikan Biologi 7(1).

Vitaloka, A. \& Sani, R.A. (2016). Inovasi Pembelajaran Fisika 4(3).

Yuliati L, Fauziah R \& Hidayat A. (2018) Journal of Physics. 1013012025.

Zetriuslita, Ariawan R, \& Nufus, H. (2016) Journal of Education and Practice 7(12) 